\title{
Evaluation of Internal Audit Operations and the Efficiency of Educational Performance in Nigerian Universities (A Case Study of Ekiti State University, Nigeria)
}

\author{
TAIWO Isaac Babatope \& ADEGOKE Victoria Adewunmi \\ Correspondence: TAIWO Isaac Babatope. E-mail: isaac.taiwo@eksu.edu.ng; taiwoib@yahoo.com;
}

Adewunmivictoria7@gmail.com

Received: September 23, 2019

Accepted: November 30, 2019

Online Published: December 2, 2019

doi:10.11114/bms.v5i4.4535

URL: https://doi.org/10.11114/bms.v5i4.4535

\begin{abstract}
This project was designed to investigate the relevance of internal audit operations in Nigerian universities to find out the extent to which an effective internal audit role has benefited the performance of the university system and how it could be used as an instrument to improve the management of the university. This was generated off by an unprecedented line up of corporate failures in the university system and how internal auditors have been belittled in the time of policy formulation and project implementation. The research employed survey research design by which data were generated through an administered questionnaire on the staff of the Internal Audit department as well as the review of available documents and records of the Ekiti State University. The data analysis used descriptive statistics and percentage analysis, and the hypotheses were tested using the t-test statistic. The research employed statistical package for social sciences (SPSS) software version 17.0 in the analysis of data and test of hypotheses which showed that internal audit operation has a relationship with the performance of the university system $(\mathrm{t}$-cal $=17.306>\mathrm{t}$-crit $=2.353$ at $5 \%$ level of significance). The research is to contribute to new knowledge by describing the internal audit profile of the Nigerian Universities to assist the university management in policy formulation and execution of projects that will lead to a better chance to maintain world-class educational societies. The research conclusion was based on the findings that there is a significant relationship between the internal audit operations and the performance of the university system, and that the management must always seek the opinion and indulgence of the internal audit department before they engage in the formulation and implementation of any policy and execution of any project.
\end{abstract}

Keywords: internal audit, internal auditors, operations, efficiency, educational performance, internal control, universities management

\section{Introduction}

There is no organization, mostly large business that can escape internal auditing (Fulop \& Szekely, 2017). Internal auditing started gaining popularity in the '40s in America. The Institute Internal Auditors (IIA) was implemented in 1941, and its development can trace back even further to an American called Lawrence Sawyer, a man who was ahead of his time and developed many of the concepts and processes that form the basis of modern internal Auditing (Mocanu \& Ciurea, 2019; Saleem, 2019). In the United Kingdom, the internal auditing standard was implemented in 1976 (Ebrahim \& Mahfoudh, 2019). In 1976, the Auditing practices committee was listed as a means of formulating the Audit processes. The first actual standards were published on April 1980 and were numerically listed. The first standard has a guideline that was listed as '101' and the guidelines were listed as '201'. By 1989, the Auditing Practices Committee (APC) started to issue practice notes, which were created to assist with the applications of guidelines and standards (Sikka, 1992).

Internal Audit takes place in a different legislative and cultural environment within the organization that differs from their scope, size, complexity, and structure; by people from the inside or outside of the organization. Although differences that can influence the practice of internal Audit can exist in every environment, it is essential to respect the international standards for the professional practice of internal Auditing set by IIA (standards for internal Auditing) to fulfill the responsibilities of internal Auditors and the activity of internal Auditing. It is pertinent to state that no organization can achieve its stated aims and objectives without internal Auditing which is to be put in place by the management of an organization through the use of internal control system to serve as a check on the effectiveness and 
efficiency of the coordination and most importantly utilization of resources entrusted to all employees in an organization on which the survival of the organization relies (Lassou, 2017).

Internal Audit is an independent appraisal function within an organization for the review of a system of control and quality of performance as a service to the organization (Millichap, 2002). From this definition, it could be seen that the work of internal audit is carried on by an internal auditor who is an employee of an organization whose work is to ensure that the internal control system is working effectively and report back to the management as a means of ensuring effectiveness, efficiency, and accountability of management operations. He is also an expert who serves as an examiner to the preparation of financial statements and examines the internal control system (Ebrahim \& Mahfoudh, 2019).

Emphatically, the university is an institution of higher learning. Preference further asserted that the university is to provide educational services and counseling to the general public at the right time. To achieve these objectives, institutions incurred expenditures both at the capital and recurrent nature, then the system of internal control is usually put in place by establishing an internal audit to ensure that the organization's objective is achieved (Udeh \& Prof. Eugene, 2016). Therefore, it is appropriate for any organization to have an effective control system by having an internal audit for good monitoring and check against the financial statements, ensure compliance with statutory requirements and safeguard the asset of the institution (Leena \& Raj, 2017).

The audit standards of England and Wales sees internal control as a whole system of control financial or otherwise, established by management to carry on the business of an enterprise in an orderly and efficient manner safeguarding its assets and secure them as safely as possible and ensuring completeness and accuracy of records (Gehya, 2016). Given this, the relevance and the need for internal audit operations cannot be overemphasized. This paper, therefore, proposes to explore the internal audit operations and its relevance in Ekiti State University, Nigeria.

\section{Statement of the Problem}

Even though internal audit has been in existence for many years in most organizations, the problem of internal management has continued to be on the increase.

In various organizations and Nigerian universities today, the roles and essence of internal audit operations, services, functions, and works are not performed or carried out efficiently and effectively; thus, rendering the internal audit department incapable and making the essence of an internal control system to go down the drain. Also, studies in Nigeria by Gbegi \& Adebisi (2015), Alao \& Amoo (2014), Abiola \& Oyewole (2013), Hamilton \& Gabriel (2012), and Adetula, Balogun, Uwajeh, \& Owolabi (2016) show that some internal control systems are weak, inadequate or not complied with. Meanwhile, Al-Atiqi \& El-Azma (2007), argued that financial monitoring and accountability of higher education had been a relevant subject matter of apprehension in many countries; assessment by Salihu (2015), has found that the components of the internal control system of internal audit are not properly put in place by the management of the institutions, all these are found in the areas of authorization and approval, supervision, segregation of duties and personnel controls, siphoning off the organization funds by the management, misappropriation of funds, execution of white elephant projects (Odia \& Odia, 2016). The implication is that the institution may lose income, which may otherwise have been utilized more usefully. Considering the above-mentioned, this research seeks to establish and bring into limelight the relevance of the existence of internal audit and their operations in Nigerian universities.

Research objectives: The objective is to examine the relationship that exists between internal audit operations and the performance of the university system with special reference to Ekiti State University Ado Ekiti and further emphasizing the need for the independence of internal auditors to show their importance and work in the institution. It's time for the accounting officers, even the management of the institution to appreciate the auditors and see reasons for their existence and operations.

Research Question: In line with the research objectives, the research question asked if there is any relationship that exists between internal audit operations and the performance of the university system.

Hypothesis: The hypotheses for research are,

$\mathbf{H}_{\mathbf{O}}$ : there is no substantial relationship between the internal audit operations and the efficiency of educational services in Nigerian universities.

$\mathbf{H}_{1}$ : there is a substantial relationship between internal audit operations and the efficiency of educational services in Nigerian universities.

\section{Literature review}

\section{Conceptual framework}

Operational internal auditing aims to improve organizational efficiency and effectiveness through constructive criticism. The concept of constructive criticism is in line with the traditional Marxist values of growth and improvement through 
criticism and self-criticism propounded by twentieth-century Marxist scholars such as Louis Althusser (Yee, Sujan, James, \& Leung, 2008).

\section{Types of Audits Performed by Internal Auditors}

The variety of audits performed in the review of institution programs (Shewamene, 2014), includes:

Compliance Audits: These determine the compliance of an institution with applicable laws, regulations, procedures, and policies, e.g., government policies, the rule of law, and the university regulations. Information Systems Audits: These audits review the internal control environment of automated information processing systems and how people use these systems. It usually evaluates system input, output; processing controls; backup and recovery plans; system security; and computer facilities.

Operations Audits: These are audits that examine the use of resources, whether they are being used effectively to fulfill the organization's mission and objectives.

Financial Audits: These are audits reviewing accounting and financial transactions to determine the commitments, authorizations, receipt, and disbursement of funds for proper and accurate records reported. This type of audit exercise determines the controls over cash and other assets and ensure that adequate controls exist in the acquisition and use of existing resources.

Internal Control Reviews: Internal audit is a concern about the components of business activities, such as payroll, cash handling, inventory, equipment, physical security, grants and contracts, and financial reporting.

\section{Concepts of Internal Control System}

This is a process of control for an organization to achieve its objectives in operational success and efficiency, dependable financial reporting, and compliance with regulations, laws, and policies. It is the necessary and adequate procedures put in place through which the assets of an organization safeguarded (Adetula et al., 2016). The America Institute of Certified Public Accountants (AICPA) defined Internal Control as "the Policies and Procedures established to generate reasonable assurance to achieve the institution objectives" (Gehya, 2016). The financial statements of Universities are required to provide information useful for making resource allocation or funding decisions. This information helps assess services provided and the ability to evaluate management stewardship, performance and economic resources, obligations, net resources, and change within the institutions (Wynne, Hadden, \& Ebbitt, 2009).

Performance: This is the ratio measurement between effort expended and results achieved. It is the process by which an organization establishes parameters within programs, investments, and acquisitions as evidence to determine progress toward specific defined organizational objectives statistically (Kipyego \& Naibei, 2017).

Efficiency: This refers to the functioning or prospering of a company at a given time in a given period basing on the desired goals and objectives of a company (Jalonen, 2019).

Definition and Purpose of Internal Audit: Internal audit may be defined as an independent appraisal function established within an organization to evaluate its activities as a service to the organization. Internal audit is a management control strategy for the effective discharge of their responsibilities. To this end, internal audit furnishes management with analyses appraisal, recommendations counsels, and information concerning the activities reviewed.

Objectives of Internal Audit: Below is the objectives of internal audit that the management expected for efficient and better performance within the university.

- Review of accounting and internal control systems.

- Examination of financial and operating information.

- Review of the three E's (economy, efficiency, and effectiveness).

- Review of compliance with laws and regulations.

- Review of arrangement for the safeguarding of assets.

- Review and implementation of corporate objectives.

- Identification of significant risk to the organization, and monitoring risk management policy and risk management strategies.

- Special investigations as required.

Internal Auditing: is an independent appraisal activity for the review of the accounting, financial, and other operations of an organization as a service to the management. 
Internal Auditor: this is an employee of an organization charged with providing independent and objective evaluations of the organization's financial and operational business, activities including its corporate governance.

External Auditor is an audit professional who performs an audit on the financial statement of an organization. He is independent of the entity being audited.

Internal Check: This is an accounting procedure for unchanging entries and transactions which are handled more than one employee in such a way that the work of one staff is automatically checked against the work of another staff for the detection of errors and irregularities.

Audits: are official inspections of an organization's account typically conducted by an independent body.

\section{Ekiti State University Principal officers and Internal Audit Structures}

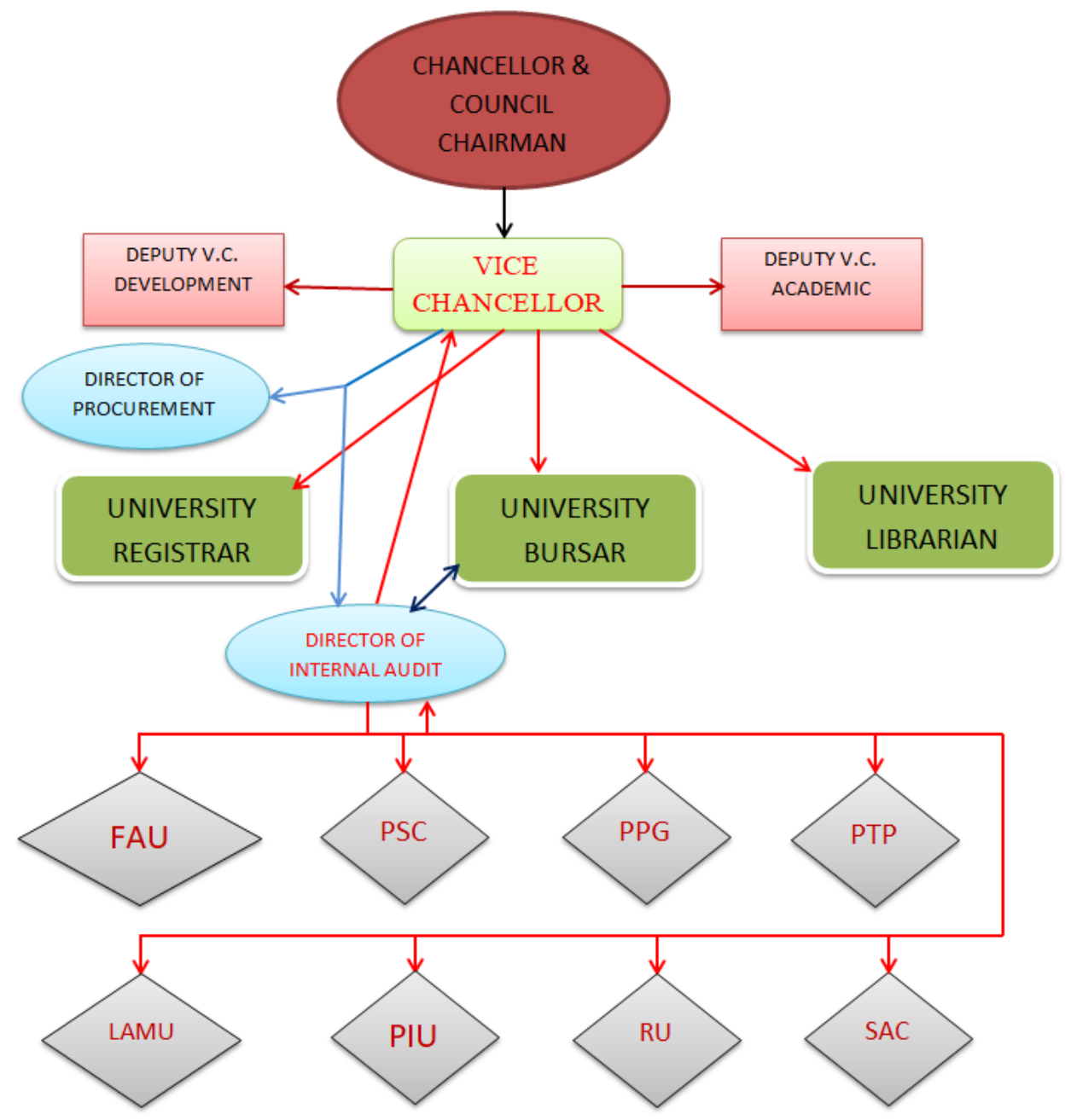

Model by Author, 2019

Meaning of the Internal Audit Units: FAU - Final Account Unit, PSC - Projects, Stores and Creditors Unit, PPG Payroll, Pension, and Gratuity Unit, PTP - Part Tine Student Account Unit, LAMU - Loan, Asset and Monitoring Unit, PIU - Price Intelligence Unit, RS - Revenue Unit and SAC - Student Account and other Academic Section

\section{Organization of the Internal Audit Department}

Considering Internal auditors within the University, they are the employees of the university, and thus, the internal audit department is of very importance to the management. Isidore (2006), asserts that the following issues must be considered in organizing the internal audit unit, Personal Qualification and Training, Size of the department, and Relationship with other functions.

\section{Organizational Structure of the University Directorate of Internal Audit}

The Directorate of internal audit of a university should be headed by a Director, who should be a professional 
Accountant, and with vast accounting and auditing experience followed by Deputy Director of Internal Audit. There should be division within the Directorate, and each division is to be headed by a Chief Internal Auditor, while the Directorate should also have various sections based on accounts within the university. Each section is headed by at least a Senior Internal Auditor. The number of divisions and sections would be determined by the size of the university and her financial accounts.

\section{Organizational Structure of the Directorate of Internal Audit in Ekiti State University}

The directorate was structured into (8) sections in five divisions.

The Directorate in a bid to achieve the enhancement of delivery of efficient and effective audit services to the university management operates the following divisions:

\section{Director's Office}

The Director's office is the anchor of the Directorate.

\section{Duties:}

Supervision of other divisions including the secretarial unit of the Directorate, Services as the link between the Vice-Chancellor and the Directorate, Responsible for the overall control of the staff and for posting of the different divisions and sections of the Directorate, and Responsible for accurate and effective reporting to the Vice-Chancellor,

\section{The (8) divisions:}

Students Account and Other Academic Section (SAC): The areas of operations in this division are, Auditing of payment vouchers in respect of students and other academic matters, Ascertainment of correctness of matriculation registers for students on all programmes, Taking charge of training and conferences for both the academic and non-teaching staff, Ascertainment of amount of revenue generated from school fees and verification of students debtors list, Ascertainment of amount due to the university from affiliated colleges, and Certification of graduating students final year clearance.

Part-Time Students Account (PTP): The areas of operation of this unit are, Auditing of students records on Part-Time Programme, Treating all payment vouchers related to the Part-Time Programme, Reconciliation of all accounts related to the Part-Time Programme, and Verification of all material purchase on the Part-Time Programme

Price Intelligence Unit (PIU): The areas of operation of this unit are, Monitoring and processing of cash advance retirement, Monitoring and supervising ant [project financed by cash advance, Processing of fueling of telephone services, grants payment vouchers, Vetting and surveys of price of goods and services, Processing and monitoring of departmental office imperest application and retirement, Processing of fuel payment vouchers and monitoring of fuel usage in the powerhouse, and Pre-audit of payment vouchers related to fueling, imperest and other procurements

Revenue Unit: This section is responsible for the auditing of the following, Revenue earning in areas of the university such as health center, school buses, sales of convocation and inaugural lecture notes, souvenirs, admission forms, staff school, and farm proceeds, etc., and Issuance of receipts booklet to the users department and recovery after usage.

Final Accounts: Finance and Ledger (FALF) Division: The areas of operation of this division are, Insurance matters, Investments, Reconciliations, Final accounts and ledger, and Monitoring of transfer of funds.

Loan, Asset and Monitoring Unit (LAMU): The areas of operation are, Auditing of utility matters such as water, PHCN, NIPOST, NITEL bills, Verification of assets and update of asset registers, and Auditing of payment vouchers in respect of various loans such as motor vehicle, refurbishing, furniture, loans, etc.

Payroll, Pension, and Gratuity Unit: The areas of operations of this division are, Auditing of payroll matters that is, salaries and wages, Auditing of pension matters, Auditing of Gratuity,

Project Stores and Creditors (PPG and PSC) Division: This division is in charge of all Stores in the university, Monitoring of projects, Ascertainment of certificate of awards before payment, Auditing of all payments vouchers related to contracts awards in the university, and Auditing of all vendors' bills to various committee in the university.

\section{Historical Background of Ekiti State University}

The Ekiti state university (EKSU) formerly Obafemi Awolowo University, which was later referred to as Ondo State University was established in the year 1982, by the then state Governor Chief (Late) Michael Adekunle Ajasin through a 16-member planning committee who suggested a philosophy and the academic objectives for the university. The university council was inaugurated in Ado-Ekiti on the $30^{\text {th }}$ of March 1982, in which Prof. I. O. Oladapo became the first Vice-chancellor, and Chief J. G. O. Adegbite was recruited as the first Registrar. Administratively, the university started modestly from an old catering rest house in Akure on the $1^{\text {st }}$ of April 1982. The recruitment of academic staff 
started in September 1982 after the setting up of a small core administrative staff headed by the Registrar, Chief J. G. O. Adegbite in August 1982. By November 1982, the university moved to a temporary site in Ado-Ekiti through which lecture started with 136 students who were admitted in three faculties: Arts, Science, and Social Sciences.

The student population rose to 3,409 in the 1988/1989 session with the faculty of Education and Engineering on the ground. On the $1^{\text {st }}$ of April 1990, Professor P. O. Bodunrin was appointed as the Vice-chancellor after the tenure of Professor I. O. Oladapo. In the 1995/1996 session, the faculty of Management Sciences was introduced together with a post-graduate diploma program. The External degree program was also established to take care of degrees and diploma courses as well as postgraduate programs that were available at outreach centers. As of then, the student enrolment was 6,100 in the six faculties. The name Ondo State University was statutorily changed to the University of Ado-Ekiti on $3^{\text {rd }}$ November 1999 as a result of the Ekiti State creation by Governor, Otunba Adeniyi Adebayo through whom an acting Vice-chancellor was appointed named Professor A. O. Ashaolu, who was eventually succeeded by Professor Akindele Oyebode and later succeeded by Professor (Mrs.) Olufunke Egunjobi as Ag.Vice-chancellor until $20^{\text {th }}$ March 2004 when Professor I. O. Orubuloye became the incumbent Vice-chancellor of the university.

Professor Dipo Kolawole was the deputy Vice-chancellor until the $19^{\text {th }}$ of March 2008 . When Professor I. O. Oroboloye retired from the service of the university and Professor Dipo Kolawole became the acting Vice-chancellor of the university. On $20^{\text {th }}$ of March 2009, the then Acting Governor of Ekiti State, Hon. Adetunji Odeyemi, appointed Professor Dipo Kolawole as the substantive Vice-chancellor of the University of Ado-Ekiti (UNAD), the position he held till $11^{\text {th }}$ of May 2011. His austere was directed by his Excellency, Dr. Kayode Fayemi, and the Executive Governor of Ekiti State. However, the merging of the three universities existing at the time in Ekiti State formed what is now known as Ekiti State University, Ado-Ekiti namely; University of Ado Ekiti, Nigeria founded in March 1982, The University of Education Ikere-Ekiti, and university of Science and Technology Ifaki-Ekiti founded by the administration of Engr. Segun Oni between 2001 and 2010. This resulted in the appointment of Professor E. Dada Adelowo as acting Vice-chancellor of the university to pave the way for the consolidation and integration of the universities and the appointment of the governing council as reconstituted to handle the appointment of a substantive Vice-chancellor among others. Professor Patrick Oladipo Aina emerged as the substantive Vice-chancellor of the university in December 2011, the post he held till December 2015, after which Professor Oye Bandele assumed the post of the Vice-chancellor of the Ekiti State University till November 2018 and presently Prof. Ajayi is the Ag. Vice-chancellor of the Ekiti State University.

\section{Mission Statement:}

In the beginning, this university was envisioned as a developmental university whose aim is to translate into a world-class center of academic excellence by making progressive and positive impact on her defined constituency, to be a problem-solving agent providing synergy to address issues of regional development and integration, and to build relevant structures required to apply knowledge to diverse situations.

\section{Brief History of the Internal Audit in the Ekiti State University, Ado Ekiti}

The internal audit was established in 1982, placed in the bursary department while the bursar deployed accountants to supervise the audit functions. The unit was however upgraded to a department and placed under the Vice-chancellor's office. The department was also upgraded to a directorate in the year 2000 and to be headed by a Director of internal audit. This was also supported by the recommendation of the committee of heads of internal audit departments in Nigeria universities (CHIADINU), and the university law. The internal audit department was established by the university as part of the control activities of the management to safeguard its assets and ensure against its liabilities. It is the organ responsible as the watchdog of compliance with the laid down policies, and that reliable set of books are to be kept by the bursary department. The head of internal audit is however responsible to the Vice-chancellor as the chief executive of the university.

Method of Keeping Records: Books and records which are kept for Institutions are the records of fixed assets, the cash and bank statements, student enrollment, academic records, payroll records, and other expenditures. Control within the university requires that documentation of records should be in a permanent file. This is an indication that not all records are important, but the important records must be typed, kept and documented for safety and should also be electronically stored, it must be duplicated in case of damage to the original records, and unauthorized persons must be prevented from having access to the records. The key important financial control within the organization centered on the transaction areas, with emphasis on safeguarding the assets of the institution and adequate maintenance of accounting records and financial information reliability (Ejoh \& Ejom, 2014). It is also essential that these records are updated regularly, and proper reconciliation should be carried out regularly on those records and any other important independent reports.

Organization Structure: To eliminate friction and promote efficiency, there should be a well-defined organizational 
structure. Experienced staff should be assigned to take up responsibilities that are relatively important to the management which required relevant skills and competence that is, an accountant to the bursary and audit department. A good organogram helps management to run business systematically, thus improving operational efficiency that helps management to have a good internal control system.

Segregation of Duties: The segregation of duties as it relates to a tertiary institution requires that no one person shall be responsible for the whole three aspects of the procedure in the institution. These aspects are Authorization, Custodian, and Recording. The simple objective of segregation of duties is that no one person is in a position to both perpetrate malpractice and at the same time conceal his action by manipulating his records.

Custodian: Institutions should establish additional rules (discipline over basic controls), to ensure that the general rules it had established are indeed being complied with. These are controls designed to physically prevent the loss of assets, cash, and inventories by ensuring that the internal control is indeed operating in compliance with the general rules.

\section{Internal Auditor as an Aid to Management}

The size of many organizations makes it impossible for top management to exercise direct supervision. An ever-widening gap this created between administration and front-line operation, because of this wide operation between operational units and headquarters, as contracts between management and its employees become more remote. Therefore, there is a need to provide room for the initiative to be applied to local conditions, and increasingly important for higher management to know the effect of their decentralization policy. Management must thereby, have the assurance that the policies and regulations that have been held down and put into operation are used by enlightened management to bridge the gap by serving as an independent check on the accounting and other operations of the organization.

However, the internal auditor has roles to play in ensuring that its management complies fully with the demand of the Sarbanes-Oxley Act (2002) and conforms to best corporate governance practices. A key requirement of the internal auditor in the emerging dispensation is that he is an internal consultant, adding value through the provision of new perspectives and insights to the university's management and board, and making recommendations that are aimed at improving performance. The import of this is that internal auditors will henceforth become active participants in the managerial process. In appraising the effectiveness of risk management processes, for instance, the internal auditor's input will of necessity precede the implementation phase. He will review the plans and purposes in the first instance before implementation. He will again come in later at the post factor monitoring phase to evaluate the outcome of the relevant measures. All these imply that the internal auditor will no longer be a bystander, watching so to speak from the sideline, what goes on in the university, only perhaps to comment thereafter on the extent to which managerial actions comply with laid down procedures and regulations.

Furthermore, Udeh \& Prof. Eugene (2016), and Adeniji (2011), states that internal audit is part of the internal control system put in place by the management of an institution with the believes that it's an aid to management better performance, which ensures that the financial operations are being carried out according to the law and also following the wishes of the board or council. Okodo, Aliu, \& Yahaya (2019), states the internal auditor's main objective is to evaluate effectiveness of financial and operating control, confirm compliance with government policies, procedure, protect assets, verify the accuracy and consistency of Organization's external and internal reports, Angus \& Mohammed (2011), argued that the objective of internal auditor is to protect management against errors of principle and neglect of duty.

\section{Functions of Internal Audit}

- Pre-payment audit of all payment vouchers to ensure that the payments are authorized and approved, the recording is accurate and is properly supported by third party documentation.

- Preparation of quarterly and annual Audit Reports on financial activities of the Fund.

- Advising management on control factors relating to all administrative and accounting procedures.

- Planning and organizing Audit Verification of beneficiary dedicated TETFUND accounts nationwide

- Planning and organizing a special authentication of various intervention projects by the Fund.

- Carrying out audit authentication of all procurements and objects received into Store and taking part in physical stock-taking exercise

- Reviewing the efficiency and effectiveness as well as the economy of the operations

- Applying civil Service Rules, Financial Regulations, Circulars, and Generally Accepted Auditing Standards in treating specific financial/auditable subjects assigned. 
- Any other duties assigned by the Management of the Fund.

\section{Audit Approach}

The auditing method taken by the internal auditor will largely depend on its responsibility and the objective assertion that the board requires.

\section{Methodology}

This research focused on the evaluation of the relevance of internal audit operations in Nigeria Universities, Ekiti State University, Ado-Ekiti as a case study.

\section{Population of Study}

The target population is the population to which a researcher tends to specify the outcome of a study (Kipyego \& Naibei, 2017). The population aims in a research study comprised all those potential participants that could make up a study group (Ondiek \& Onono, 2016; Shewamene, 2014). It has been observed that the objective of the study is to examine the relevance of internal audit operations in Nigeria Universities. However, in a study of this nature, where the population size is very large, a sample of the total population can be regarded as a true representative of the population that was used to gather the needed information. The study population consisted of 56 staff working in the directorate of internal audit in Ekiti State University, Ado-Ekiti, Nigeria.

\section{Sample Size}

The sample size consists of the respondents drawn based on their vast experience and knowledge about the research together with their year of service within the University Internal Audit Directorate. Therefore, a sample size number of 24 respondents was drawn from the population, which consists of 3members of staff from each of the eight divisions of the directorate.

\section{Research Instrument and Validity}

Peculiar nature of the research topic and conditions for obtaining official information from the staff caused the use of the qualitative method. Data were collected through primary source using semi-structured questionnaires with well-structured questions that gave the respondents limited and predetermined response option to choose from. The questionnaire was adapted from the study of (Tracy, 2011), controlled using a drop and picks a method, and consists of four sections. Section A deals with information about the respondents, and Section B examined the relationship that exists between internal audit operations and the performance of the university system.

\section{Methods of Data Analysis}

The descriptive statistics with cross-tabulation and simple percentages were used, the research employed statistical package for social sciences (SPSS) software version 17.0 in the analysis of data, and t-test was used to seek the relationship between study variables and hypothesis.

\section{Description of Tools of Analysis}

The mean (X)

$$
\mathrm{X}=\frac{\Sigma f x}{\Sigma f}
$$

The standard deviation (SD)

$$
\delta=\frac{\sqrt{\sum f(x-\xi) 2}}{\Sigma f}
$$

The Chi-square

$$
\mathrm{X}=\frac{\Sigma(O-E)}{\Sigma}
$$

Where:

$\sum$ means summation

$f \quad$ means frequency

$\mathrm{X}$ means variable

n means the total number of observations

$O$ means observed the frequency 


\section{E means the expected frequency}

\section{Findings}

This serves as a guideline for conclusion and recommendation and data collected are presented using tables to clearly show the responses obtained and the use of percentages and t-test statistic techniques was used to test hypothesis guiding the study.

\section{Data Analysis:}

Table 1. Shows the number of questionnaires administered

\begin{tabular}{l|l|l|l}
\hline Respondents & $\begin{array}{l}\text { No of Questionnaire } \\
\text { administered }\end{array}$ & No of a questionnaire answered & Percentage (\%) \\
\hline Staff & 24 & 24 & 100 \\
\hline Total & 24 & 24 & 100 \\
\hline
\end{tabular}

From the table, 24 questionnaires were distributed, and all were answered by the respondents.

Table 2. Shows the gender of the respondents

\begin{tabular}{l|l|l}
\hline Gender & Respondents & Percentage $(\%)$ \\
\hline Male & 8 & 33.3 \\
\hline Female & 16 & 66.7 \\
\hline Total & 24 & 100 \\
\hline
\end{tabular}

From the table, $33.3 \%$ of the respondents are male, while $66.7 \%$ are Female.

Table 3. Shows the age of the respondents

\begin{tabular}{l|l|l}
\hline Age (Years) & Responses & Percentage $(\%)$ \\
\hline $18-25$ & 2 & 8 \\
\hline $26-35$ & 8 & 33 \\
\hline 36 years and above & 14 & 59 \\
\hline Total & 24 & 100 \\
\hline
\end{tabular}

From the table above, $8 \%$ of the population is between the ages of $18-25,33 \%$ of the respondents are between the ages of $26-35$, and $59 \%$ are above 36 years of age.

Table 4. Shows the marital status of the respondents

\begin{tabular}{l|l|l}
\hline Marital Status & Responses & Percentage (\%) \\
\hline Single & 2 & 8 \\
\hline Married & 22 & 92 \\
\hline Divorced & 0 & 0 \\
\hline Widowed & 0 & 0 \\
\hline Total & 24 & 100 \\
\hline
\end{tabular}

From the table, $2(8 \%)$ of the respondents are single, while $22(92 \%)$ are married, $0 \%$ are divorced and widowed.

Table 5. Shows the educational qualification of the respondents

\begin{tabular}{l|l|l}
\hline Qualification & Responses & Percentage (\%) \\
\hline SSCE & 0 & 0 \\
\hline ND/NCE & 0 & 0 \\
\hline HND & 4 & 17 \\
\hline B.Sc & 14 & 58 \\
\hline Others & 6 & 25 \\
\hline Total & 24 & 100 \\
\hline
\end{tabular}

From the table, $0 \%$ of the respondents have SSCE qualification, $0 \%$ have ND/NCE qualification, 4 (17\%) have HND qualification, 14 (58\%) have BSc. qualification while 6 (25\%) have other qualification e.g., Ph.D., etc.

Table 6. Shows Position in the Organization

\begin{tabular}{l|l|l}
\hline Position & Responses & Percentage (\%) \\
\hline Senior Staffs & 8 & 33.3 \\
\hline Junior Staffs & 16 & 66.7 \\
\hline Total & 24 & 100 \\
\hline
\end{tabular}


The above question was an open-ended question to know which position the respondents are holding in the university. The analysis indicates that out of the 24 respondents, 8 (33.3\%) are Senior Staffs (Director, Chief Internal Auditor, Principal Internal Auditor, Senior Internal Auditor, Internal Auditor I and Internal Auditor II) and 16 (66.7\%) are Junior Staffs (Executive officer Audit and Clerical Staff).

Table 7. Shows the work experience of the respondents

\begin{tabular}{l|l|l}
\hline Experience & Respondents & Percentage (\%) \\
\hline None & 3 & 13 \\
\hline Yes & 21 & 87 \\
\hline Total & 24 & 100 \\
\hline
\end{tabular}

From the table, $13 \%$ of the respondents have no work experience, while $87 \%$ have.

Table 8. Shows the field of study of the respondents

\begin{tabular}{l|l|l}
\hline Field & Respondents & Percentage (\%) \\
\hline Economics & 8 & 33 \\
\hline Accounting & 14 & 59 \\
\hline Banking \& Finance & 2 & 8 \\
\hline Total & 24 & 100 \\
\hline
\end{tabular}

From the table, $33 \%$ of the respondents studied Economics, 59\% studied Accounting, while $8 \%$ of the respondents studied Banking and Finance.

Table 9. Shows the Audit Unit of the respondents

\begin{tabular}{l|l|l}
\hline Department & Respondents & Percentage (\%) \\
\hline Project, Stores, and Creditors & 3 & 12.5 \\
\hline Student Account and other Academic Section & 3 & 12.5 \\
\hline Price Intelligence Unit & 3 & 12.5 \\
\hline Final Account & 3 & 12.5 \\
\hline Payroll, Pension, and Gratuity & 3 & 12.5 \\
\hline Part-Time Student Account & 3 & 12.5 \\
\hline Revenue Se Revenue Section & 3 & 12.5 \\
\hline Revenue Se Loan, Asset and Monitoring & 3 & 12.5 \\
\hline
\end{tabular}

\section{Analysis of the Research Questions}

Decision Rule: If mean $<2.5$, then respondents agree

If the mean $\geq 2.5$, the respondents disagree

Table 10. Responses and Percentage on whether internal audit operation has an impact on the performance of the University system

\begin{tabular}{l|l|l|l|l|l|l|l}
\hline Options & SA & A & U & D & SD & Mean & Std. Dev. \\
\hline Number of responses & 19 & 5 & 0 & 0 & 0 & 1.43 & 0.73 \\
\hline Percentage (\%) & 79 & 21 & 0 & 0 & 0 & & \\
\hline
\end{tabular}

Source: Field Survey 2019

In other to the determining whether Internal audit operation has an impact on performance of the University system, responses in Table 10 shows that $79 \%$ of respondents strongly agreed, $21 \%$ respondents agreed, $0 \%$ respondents were undecided, $0 \%$ respondents strongly disagree, and $0 \%$ respondents strongly disagree that Internal audit operation has impact on performance of University system. 
Table 11. Responses and Percentage on whether there is a need for the existence of an internal audit department in the university

\begin{tabular}{l|l|l|l|l|l|l|l}
\hline Options & SA & A & U & D & SD & Mean & Std. Dev. \\
\hline Number of responses & 16 & 6 & 2 & 0 & 0 & 1.44 & 0.55 \\
\hline Percentage (\%) & 67 & 25 & 8 & 0 & 0 & & \\
\hline
\end{tabular}

Source: Field Survey 2019

Table 11 shows that $67 \%$ of respondents strongly agreed, $25 \%$ of respondents agreed, $8 \%$ of respondents being undecided, $0 \%$ respondents disagree, and $0 \%$ respondents strongly disagree that there is a need for the existence of internal audit department in the university.

Table 12. Response and Percentage on if internal audit operations are necessary for the university

\begin{tabular}{l|l|l|l|l|l|l|l}
\hline Options & SA & A & U & D & SD & Mean & Std. Dev. \\
\hline Number of responses & 15 & 9 & 0 & 0 & 0 & 1.30 & 0.75 \\
\hline Percentage (\%) & 63 & 37 & 0 & 0 & 0 & & \\
\hline
\end{tabular}

Source: Field Survey 2019

Table 12 shows that 15 respondents representing (63\%) strongly agree, 9 representing (37\%) of the respondents agreed, while 0 representing $(0 \%)$ of the respondents are undecided and $0(0 \%)$ respondents disagree while $0(0 \%)$ strongly disagree that Internal audit operation is necessary for the university.

Table 13. Responses and Percentage on whether one agrees that internal audit is an aid to management

\begin{tabular}{l|l|l|l|l|l|l|l}
\hline Options & SA & A & U & D & SD & Mean & Std. Dev. \\
\hline Number of responses & 15 & 9 & 0 & 0 & 0 & 1.30 & 0.75 \\
\hline Percentage (\%) & 63 & 37 & 0 & 0 & 0 & & \\
\hline
\end{tabular}

Source: Field Survey 2019

Table 13 shows that 15 respondents representing (63\%) strongly agree, 9 representing (37\%) of the respondents agreed, while 0 representing $(0 \%)$ of the respondents are undecided and $0(0 \%)$ respondents disagree while $0(0 \%)$ strongly disagree that internal audit is an aid to management.

\section{Test of Hypothesis}

$\mathbf{H}_{\mathbf{0}}$ : there is no substantial relationship between the internal audit operations and the efficiency of educational services in Nigerian universities.

$\mathbf{H}_{1:}$ there is a substantial relationship between the internal audit operations and the efficiency of educational services in Nigerian universities.

Table 14. Shows T-Test Descriptive Statistics

\begin{tabular}{l|l|l|l|l|l|l}
\hline $\mathrm{N}$ & Mean & Std.Dev. & Df & T-cal & T-cri & Remark \\
\hline 4 & 1.4234 & 0.15 & 3 & 17.312 & 2.334 & rejected \\
\hline
\end{tabular}

As presented in the above table, the calculated t-test value is 17.312. This value is greater than the critical t-test value of 2.334 , i.e $\mathrm{t}$-cal (17.312) > t-crit (2.334) at 5\% level of significance. As a result of this, the null hypothesis is rejected, and the alternative hypothesis is accepted in that, there is a substantial relationship between the internal audit operations and the efficiency of educational services in Nigerian universities.

\section{Summary of findings, conclusion, and recommendation}

In completion of the research work, from the data collected from the samples also the test of hypothesis revealed that there is a relationship that exists between internal audit operations and the performance of university system, the failure of the institution to recognize and acknowledge the need for their existence will be like a lost treasure. Also, it will help to know a way forward for progress for the organization. From the test of the hypothesis, it shows that internal audit operations have an impact on the performance of the university system. There is also a relationship between the effectiveness and reliance of the internal audit system and the efficiency of educational performance. Thus the non-existence of internal audit system in the institution will lead to inefficiency most importantly in the affairs and activities of the management of the institution because if a high and effective working standard which has been tested and approved through the use of internal audit system and internal checking is set and implemented by the management, then it will ensure the spread of efficiency abroad the institution. Therefore, a properly conducted internal audit may reveal discrepancies, mistakes, loop-holes, and fraudulent manipulations in the educational performance of the university system. 
Conclusion: The study, taken together with our research question, research hypothesis, and the role played by the internal audit department for the overall management policies across the Nigerian Universities. Internal audit is an important mechanism to ensure sound corporate governance. The results on the existence of useful internal audit functions as an internal control management system in the universities improve efficiency and effectiveness, reduce information asymmetry during decision making, and ensures internal reliability of the financial reporting process. The results can underwrite and modified that the purpose of internal auditing is not only to discover fraud, but it goes a long way to determining the quality of services. Hence, monies will be made available for adequate funding of every activity of the institution. Internal audit is a key to a productive and successful management decision; it's also a life wire of the institution that keeps it going smoothly and efficiently. The study will serve as a basis for future research that might extend, refine, and qualify our findings.

Recommendations: Sequel to these findings and conclusions, it has been proved beyond doubt that the relevance and importance of internal audit operations cannot be overemphasized. Therefore, a standard internal audit department must be created and be seen to be independent to ensure adequate and professional discharge of their duties and operations. The department must be recognized and respected in the institution and management in the institutions must not disregard the work and effort of internal auditors, they should, therefore, give support to enhance the effectiveness of audit integrity, objectivity, and professional independence. Management must always seek the professional contribution of the internal audit department before they engage in the formulation and implementation of any policy and execution of any project within the university.

\section{Suggestions for further study}

The study evaluated the relevance of internal audit operation in Nigeria University, focusing on a case study of Ekiti State University. This study recommends that further study should be carried out on the factors that influence the relevance of internal audit operation in public institutions.

\section{References}

Abiola, I., \& Oyewole, A. T. (2013). Internal control system on fraud detection: Nigeria experience. Journal of Accounting and Finance, 13(5), 141-152.

Adeniji, A. A. (2011). Auditing and Investigations. Wyse Associates Limited, Ikeja Nigeria.

Adetula, D. T., Balogun, S., Uwajeh, P., \& Owolabi, F. (2016). Internal control system In the nigerian tertiary institutions. Innovation Management and Education Excellence Vision 2020: Regional Development to Global Economic Growth, 4505-4508.

Alao, A. A., \& Amoo, A. A. (2014). Enhancing the performance of electricity distribution companies in Nigeria via internal control system. Research Journal of Finance and Accounting, 5(22), 197.

Al-Atiqi, I. M., \& El-Azma, M. (2007). Funding and financial performance of private higher education institutions in Kuwait. Paper presented at UNESCO forum on higher education, research and knowledge on the impact of globalization on higher education and research in the Arab states, May 2007, Rabat, Morocco.

Angus, O. U., \& Mohammed, I. K. (2011). Effectiveness of internal audit as instrument of improving public sector management. Journal of Emerging Trends in Economics and Management Sciences (JETEMS), 2(4), 304-309.

Ebrahim, M. A.-M., \& Mahfoudh, H. M. (2019). The Moderating Effect Of Internal Audit on the Relationship between Corporate Governance Mechanisms and Corporate Performance among Saudi Arabia Listed Companies. Contaduría y Administración, 65(1), 1-36. https://doi.org/10.22201/fca.24488410e.2020.2316

Ejoh, N. O., \& Ejom, P. E. (2014). the Effect of Internal Audit Function on the Financial Performance of Tertiary Institutions in Nigeria. International Journal of Economics, Commerce and Management, II(10), 1-14.

Fulop, M. T., \& Szekely, S. V. (2017). The evolution of the internal auditing function in the context of corporate transparency. Audit Financiar, 15(147), 440-450. https://doi.org/10.20869/auditf/2017/147/440

Gbegi, D. O., \& Adebisi, J. F. (2015). Analysis of fraud detection and prevention strategies in the Nigerian public sector. Journal of Good Governance and Sustainable Development in Africa, 2(4), 109-128.

Gehya, F. E. (2016). The Role of Internal Audit in Enhancing Accountability in Tertiary Institutions in Kogi State, Nigeria, 7(14), 1-8.

Hamilton, D. I., \& Gabriel, J. M. O. (2012). Dimensions of fraud in Nigeria quoted firms. American Journal of Social and Management Sciences, 3(3), 112-120. https://doi.org/10.5251/ajsms.2012.3.3.112.120

Institute of Internal Auditors (IIA), (1999). Definition of Internal Auditing, The Institute of Internal Auditors, Altamonte Springs, FL. 
Isidore, O. N. (2006). Auditing Concepts, Issues and Principles. Lagos Nigeria IONAG Investment Company limited.

Jalonen, H. (2019). You get what you ask for? Encountering complexity and performative leadership on social media. ACM International Conference Proceeding Series, 64-69. https://doi.org/10.1145/3328886.3328890

Kipyego, L., \& Naibei, I. K. (2017). Accounting Internal Control Systems and Firm Performance: Evidence From Commercial Banks in Kericho Count. Kenya, V(11), 697-712.

Lassou, P. J. C. (2017). State of government accounting in Ghana and Benin: a "tentative" account. Journal of Accounting in Emerging Economies, 7(4), 486-506. https://doi.org/10.1108/jaee-11-2016-0101

Leena, H. K., \& Raj, N. P. (2017). Chatham House Report Collective Action on Corruption in Nigeria. The Royal Institute of International Affairs, 1-53. Retrieved from http://www.chathamhouse.org/sites/default/files/publications/research/2017-05-17-corruption-nigeria-hoffmann-pa tel.pdf

Millichamp, A. H. (2002). Auditing: An Instructional Manual for Accounting Students. Ashor Colour press 7th edition.

Mocanu, M., \& Ciurea, C. (2019). Developing an Index Score for the Internal Auditor Profile in Romania Based on Real Data Analysis. Economic Computation and Economic Cybernetics Studies and Research, 53(2/2019), 93-111. https://doi.org/10.24818/18423264/53.2.19.06.

Odia, J. O., \& Odia, A. A. (2016). E- Government and Corruption in Nigeria : the Case of Treasury Single Account (TSA). Afro Asian Journal of Social Sciences, VII(Iv), 1-25.

Okodo, B. D., Aliu, M. M., \& Yahaya, A. O. (2019). Assessing the Reliability of Internal Audit Functions : The Issues Assessing the Reliability of the Internal Audit Functions: The Issues. Journal of Contemporary Research in Business, Economics and Finance, 1(1), 46-55.

Ondiek, B. A., \& Onono, P. (2016). Internal Audit System on Financial Performance in Public Health Sector in Kenya. International Journal of Economics, Commerce and Management, IV(12), 514-523.

Saleem, K. S. A. (2019). The Impact of Audit Committee Characteristics on the Creative Accounting Practices Reduction in Jordanian Commercial Banks. Modern Applied Science, 13(6), 113-123. https://doi.org/10.5539/mas.v13n6p113

Salihu, A. M. (2015). Impact of internal audit unit on the effectiveness of internal control system of tertiary educational institutions in Adamawa State, Nigeria. International Journal of Humanities Social Sciences and Education, 2(5), $140-156$.

Shewamene, H. (2014). Determinants of Internal Audit Effectiveness in the Public Sector, Case Study in Selected Ethiopian Public Sector Offices. JIMMA University, College of Business and Economics Department, Thesis Work, $1-73$.

Sikka, P. (1992). Audit policy making in the UK the case of 'the auditor's considerations in respect of going concern. European Accounting Review, 1(2), 349-392. https://doi.org/10.1080/09638189200000027

Tracy, D. (2011). Quality Client Survey. The Institute of Internal Auditors, 1-3.

Udeh, S. N., \& Prof. Eugene, O. N. (2016). Evaluation of effectiveness of internal audit in the nigerian public sector. European Journal of Business, Economics and Accountancy, 4(3), 44-58.

U.S. House of Representatives. (2002). The Sarbanes-Oxley Act of 2002 - (SOX), Public Law 107-204 [H.R.3763]. Washington, D.C.: Government Printing Office.

Wynne, A., Hadden, D., \& Ebbitt, J. (2009). International Consortium on Government Financial Management. International Journal of Governmental Financial Management, IX(2), 1-102. https://doi.org/10.1111/j.1468-2362.2009.01249.x

Yee, C. S. L., Sujan, A., James, K., \& Leung, J. K. S. (2008). Perceptions of Singaporean internal audit customers regarding the role and effectiveness of internal audit. Asian Journal of Business and Accounting, 1(2), 147-174.

\section{Copyrights}

Copyright for this article is retained by the author(s), with first publication rights granted to the journal.

This is an open-access article distributed under the terms and conditions of the Creative Commons Attribution license which permits unrestricted use, distribution, and reproduction in any medium, provided the original work is properly cited. 